International Journal of Current Advanced Research

ISSN: O: 2319-6475, ISSN: P: 2319 - 6505, Impact Factor: SJIF: 5.995

Available Online at www.journalijcar.org

Volume 6; Issue 3; March 2017; Page No. 2613-2615

DOI: http://dx.doi.org/10.24327/ijcar.2017.2615.0057

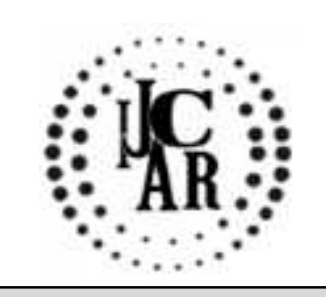

Research Article

\title{
DIURETIC ACTIVITY OF HYDRO-ALCOHOLIC EXTRACTS OF NYCTANTHES ARBORTRISTIS IN ALBINO RATS
}

\author{
Joshi Ankur ${ }^{*}$., Soni Priyanka ${ }^{2}$., Malviya Sapna ${ }^{1}$ and Kharia Anil ${ }^{1}$ \\ ${ }^{1}$ Modern institute of Pharmaceutical Sciences, Indore \\ ${ }^{2}$ Acropolis Institute of Pharmaceutical Education \& Research, Indore
}

\begin{abstract}
A R T I C L E I N F O
Article History:

Received $19^{\text {th }}$ December, 2016

Received in revised form $20^{\text {th }}$ January, 2017

Accepted $26^{\text {th }}$ February, 2017

Published online $28^{\text {th }}$ March, 2017

\section{Key words:}

Diuretics, Nyctanthes arbortristis, Furosemide, Soduim, and Potassium

A B S T R A C T

In the present study hydro-alcoholic extract of Nyctanthes arbortristis was prepared using soxhlet's apparatus. Albino rats were divided into 5 groups of 6 rats each. Group-I (Control) received distilled water $25 \mathrm{ml} / \mathrm{kg}$ orally. Group-II (Standard). received Furosemide $20 \mathrm{mg} / \mathrm{kg}$ orally. Group-III received hydro-alcoholic extract of Nyctanthes arbortristis $100 \mathrm{mg} / \mathrm{kg}$, Group-IV received hydro-alcoholic extract of Nyctanthes arbortristis $200 \mathrm{mg} / \mathrm{kg}$ and Group-V received hydro-alcoholic extract of Nyctanthes arbortristis $400 \mathrm{mg} / \mathrm{kg}$. The urine samples were collected for all the groups upto 5 hours after dosing and urine volume was measured. Urine was analysed for electrolytes (Na+, $\mathrm{K}+$ and $\mathrm{Cl}-$ ). ANOVA, Dunnet's test and p-values were measured and data was analysed. hydro-alcoholic extract of Nyctanthes arbortristis exhibited significant diuretic activity by increasing urine volume and also by enhancing elimination of Sodium $(\mathrm{Na}+)$, Potassium $(\mathrm{K}+)$ and Chloride (Cl-) at doses of 100 and $200 \mathrm{mg} / \mathrm{kg}$. hydro-alcoholic extract of Nyctanthes arbortristis possesses significant diuretic activity.
\end{abstract}

Copyright $\odot 2017$ Joshi Ankur. This is an open access article distributed under the Creative Commons Attribution License, which permits unrestricted use, distribution, and reproduction in any medium, provided the original work is properly cited.

\section{INTRODUCTION}

Cardiac failure is a syndrome resulting from impaired pumping capacity of the heart which occurs because of genetic or acquired abnormality in cardiac structure and/ or function. This results in symptoms and signs of cardiac failure such as dyspnea, fatigue, oedema, rales leading to frequent hospitalization, a poor quality of life and a shortened life expectancy [1]. Inspite of high rates of morbidity and mortality, the pathophysiologic mechanisms and treatment of heart failure is poorly understood.

Body hydration status is of remarkable importance. Diuretics elevate the rate of urine flow and sodium excretion and are used to adjust the volume and/ or composition of the body fluids and this includes forced diuresis. Diuretics can adequately control fluid retention and restore and maintain normal volume status in patients with congestive symptoms (dyspnoea, orthopnoea, oedema) or signs of elevated filling pressures (rales, jugular venous distension, or peripheral oedema). Diuretics adjust the volume and composition of body fluids in a variety of clinical situations including hypertension, heart failure, renal failure, nephrotic syndrome, and cirrhosis [2]. The currently used diuretics are usually associated with many adverse reactions.

*Corresponding author: Joshi Ankur,

Modern institute of Pharmaceutical Sciences, Indore
Various plant extracts used in traditional medicine have shown significant diuretic activity when tested in animal models. In this current study an attempt has been made to evaluate the diuretic activity of hydro-alcoholic leaves extract of Nyctanthes arbortristis.

Nyctanthes arbortristis (N. arbortristis) is a valuable medicinal plant which belongs to the family Oleaceae. The plant generally grows in tropical and subtropical region. $\mathrm{N}$. arbortristis commonly known as Night jasmine, Harsinghar \& Parijat. The flowers start falling after midnight and by the day break, the plant appears dull. The generic name 'Nyctanthes' has been coined from two Greek words 'Nykhta' (Night) and 'anthos' (flower) [3,4]. It is usually a shrub or a small tree having brilliant, highly fragrant flowers, which bloom at night and fall off before sunrise, giving the ground underneath a pleasing blend of white and red. Thus, during the day the plant loses all its brightness and hence is called "Tree of sadness" (arbor - tristis). It is also known as arsinghar, Coral Jasm ine, Parijat, queen of the night and night flowering jasmine [5]. It is a Nyctanthes arbortristisive of India, distributed in sub - Himalayan region and also found in Indian garden as ornamental plant. In India, it grows in the outer Himalayas and is found in tracts of Jammu and Kashmir, Nepal to East of Assam, Bengal, Tripura extended through the Central region up to Godavari in the South. Flowering usually occurs from July to October. N. arbortristis prefers a secluded and semi-shady place to grow [6]. 
$\mathrm{N}$. arbortristis is one of the well known medicinal plant. It is a common wild hardy large shrub or small tree. Different parts of this plant are used in Indian systems of medicine for various pharmacological actions like as anti-leishmaniasis, anti-viral, anti-fungal, anti-pyretic, anti-histaminic, antimalarial, anti-oxidant [7], anti-inflammatory [8] and many more activities.

Herbs have been always the main principle form of medicine since traditions in India and now a day it becomes most popular throughout the world. Important large shrub of tropical and subtropical regions of the world that has been traditionally used to provoke menstruation, for treatment of scabies and other skin infections as hair tonic [9]

\section{MATERIALS AND METHODS}

\section{Animals}

Albino rats (150-200g) of either sex were randomly selected from central animal facility, Modern Institute of Pharmaceutical Sciences,Indore. Animals were housed into groups of six per cage at a controlled temperature $\left(23 \pm 2^{\circ} \mathrm{C}\right)$. Light: dark cycle of 12:12 was followed. The rats had free access to standard pelleted feed and water ad libitum. The Institutional Animal Ethical Committee approved the protocol of this study.

\section{Preparation of the extract and isolation of active principle}

The plant material is made up of the leaves of Nyctanthes arbortristis. The leaves was collected from medicinal garden of Modern institute of Pharmaceutical Sciences in August 2016. The sample of plant was identified and authenticated at Rajmata Vijayraje Scindia Krishi Vishwavidhalaya, College of Agriculture, Indore A weighed quantity (200g) of the powder was then subjected to continuous hot extraction in Soxhlet apparatus with hydro-alcoholic. The extract was filtered through a cotton plug, followed by Whartman filter paper (No.1) and dried at $40-50^{\circ} \mathrm{C}$ to get a blackish green semisolid mass, which was taken for final use. hydro-alcoholic leaves extract of Nyctanthes arbortristis at doses of 100,200 and $400 \mathrm{mg} / \mathrm{kg}$ respectively, all of which were administered orally immediately prior to the test in this acute study. The hydro-alcoholic leaves extract of Nyctanthes arbortristis extracts of the test drug were suspended in distilled water for oral administration.

\section{Assessment of diuretic activity}

Albino rats weighing 150-200 g were used. The rats were fed with standard pellet diet and provided water ad libitum. The same was withheld 18 hours prior to the experiment. They were hydrated with $5 \mathrm{ml} / \mathrm{kg}$ of distilled water prior to drug/extract administration. Immediately after dosing the animals were placed in metabolic cages provided with a wire mesh bottom and a funnel to collect the urine. Stainless-steel sieves were placed in the funnel to retain feces and to allow the urine to pass. The urine was collected in measuring cylinder up to five hours after dosing. During this period, animals were deprived of food and water [11]. The volume was measured and urine sample kept in refrigerator until $\mathrm{Na}+$, $\mathrm{K}+$ and $\mathrm{Cl}-$ levels were estimated. The urine samples were kept without adding any preservatives. The concentrations of urine $\mathrm{Na}+$ and $\mathrm{K}+$ were determined by flame photometry and concentration of Cl- was estimated titrimetrically using $0.02 \mathrm{~N}$ $\mathrm{AgNO}_{3}$ with $5 \%$ potassium chromate as indicator.

\section{Statistical analysis}

The effects of hydro-alcoholic leaves extract of Nyctanthes arbortristis were calculated by taking the Mean values and Standard Deviation of the outcome parameters. ANOVA (Analysis of Variance) was applied to compare the effects of drugs under study. The data were analysed using ANOVA followed by Dunnett's test

\section{RESULTS}

Oral administration of single dose of hydro-alcoholic leaves extract of Nyctanthes arbortristis significantly increased the urine output at the doses of 100 and $200 \mathrm{mg} / \mathrm{kg}$.

Table No. 1 Effects of oral administration of hydro-alcoholic leaves extract of Nyctanthes arbortristis on urine volume and electrolyte excretion

\begin{tabular}{cccccc}
\hline Treatment & Dose & Urine & $\mathbf{N a}$ & $\mathbf{K}+$ & $\mathbf{C l}-$ \\
\hline group & $($ Oral $)$ & volume $(\mathrm{ml})$ & $(\mathrm{mEq} / \mathrm{L})$ & $(\mathrm{mEq} / \mathrm{L})$ & $(\mathrm{mEq} / \mathrm{L})$ \\
Control & 25 & $2.93+0.20$ & $112.00+2.52$ & $48.75+1.20$ & $160.50+4.32$ \\
& $\mathrm{ml} / \mathrm{kg}$ & & & & \\
Standard & 20 & $8.43+0.89$ & $140.33+1.86$ & $90.70+1.44$ & $314.50+12.48$ \\
& $\mathrm{mg} / \mathrm{kg}$ & & & & \\
Test- 1 & 100 & $5.80+0.35^{*}$ & $131.50+1.64 *$ & $55.61+3.15^{*}$ & $263.00+4.14 *$ \\
& $\mathrm{mg} / \mathrm{kg}$ & & & & \\
Test- 2 & 200 & $5.23+0.40^{*}$ & $128.16+4.95^{*}$ & $66.31+3.41^{*}$ & $170.33+7.89 *$ \\
& $\mathrm{mg} / \mathrm{kg}$ & & & & \\
Test- 3 & 400 & $5.16+0.56^{*}$ & $120.16+3.31$ & $81.93+3.60^{*}$ & $155.50+3.21$ \\
& $\mathrm{mg} / \mathrm{kg}$ & & & & \\
\hline
\end{tabular}

\section{Drugs and chemicals}

Furosemide $20 \mathrm{mg} / \mathrm{kg}$ body weight (Lasix 20mg) (Sanofi Aventis India Limited), hydro-alcoholic leaves extract of Nyctanthes arbortristis 100, 200 and $400 \mathrm{mg} / \mathrm{kg}$ body weight and distilled water.

Animals were divided into five groups (with six rats each). Animals were deprived of food and water for 18 hours prior to the experiment. Group I received $25 \mathrm{ml} / \mathrm{kg}$ of distilled water and served as the control, Group II received Furosemide $20 \mathrm{mg} / \mathrm{kg}$ as standard [10], Groups III, IV and V received
The effect was found to be dose dependent with more pronounced outflow at $100 \mathrm{mg} / \mathrm{kg}$ ( $\mathrm{p}<0.01 \mathrm{vs}$ control) and the results were not significant when the dose was increased to $400 \mathrm{mg} / \mathrm{kg}$ as indicated in [Table-1].

The effect of hydro-alcoholic leaves extract of Nyctanthes arbortristis on the excretion of urinary electrolytes is dose dependent. The test doses of $100 \mathrm{mg} / \mathrm{kg}$ and $200 \mathrm{mg} / \mathrm{kg}$ significantly increased the excretion of all the electrolytes $\mathrm{Na}+, \mathrm{K}+$ and $\mathrm{Cl}$-estimated in the study. However, the test drug at higher dose of $400 \mathrm{mg} / \mathrm{kg}$ did not induce any significant increase in the $\mathrm{Na}+$ and $\mathrm{Cl}-$ excretion. 


\section{DISCUSSION}

Fluid overload is usually observed in various pathological states such as cardiac failure and secondary oliguric states. Heart failure is the leading cause of hospitalization in people older than 65. More than 20 million people have heart failure worldwide [12]. The prevalence and incidence of heart failure in India has been estimated to range from 1.3 to 4.6 million, with an annual incidence of 0.5- 1.8 million [13]. Inspite of high rates of morbidity and mortality, the pathophysiologic mechanisms and treatment of heart failure is poorly understood. Even with the advent of newer and selective agents, their side effect profile is a setback and also few cases show refractoriness to conventional treatment. The current study was aimed at evaluating the diuretic activity of hydroalcoholic leaves extract of Nyctanthes arbortristis in albino rats.

Diuretics used in the treatment of heart failure act by enhancing urine outflow, decreasing plasma volume and venous return to the heart, and thereby subsequently decrease cardiac workload, oxygen demand and blood pressure. The major site of action of the loop diuretic, furosemide is the thick ascending limb of loop of Henle where it acts by inhibiting the $\mathrm{Na}+/ \mathrm{K}+/ 2 \mathrm{Cl}$ - co-transport carrier in the luminal membrane. It increases the urine output along with increased urinary excretion of $\mathrm{Na}+\mathrm{K}+$ and $\mathrm{Cl}-$.

The present study showed that the diuretic activity of the hydro-alcoholic leaves extract of Nyctanthes arbortristis is relatively modest and slow in onset as compared to the reference drug, furosemide. The plant extract also caused increased urine volume and increased urinary excretion of $\mathrm{Na}+, \mathrm{K}+$ and $\mathrm{Cl}$ - like that of furosemide

Therefore the probable diuretic action of hydro-alcoholic leaves extract of Nyctanthes arbortristis could be due to its interference with the $\mathrm{Na}+/ \mathrm{K}+/ 2 \mathrm{Cl}$ - co-transport carrier in the luminal membrane of the thick ascending limb of loop of Henle, similar to the mechanism of action of furosemide. And, this effect of the extract may be related mainly to the sugar mannitol.

hydro-alcoholic leaves extract of Nyctanthes arbortristiwas observed to have diuretic activity in experimentally induced diuresis in albino rats. The study explores the complementary nature of Nyctanthes arbortristiwas with conventional treatment making it comparatively safer, economical, easily available and well tolerated therapy.

\section{CONCLUSION}

We conclude from the study that Nyctanthes arbortristi was has a beneficial role as a diuretic and thereby support the claim of traditional use of the plant as a diuretic. Further studies are indicated to identify the adverse effects, optimal treatment routes and dosage.

\section{Acknowledgement}

The authors are grateful to the Shri Arun Kharia, President, Modern Group, Shri Anil Kharia, Principal Modern Institute of Pharmaceutical Sciences Indore, and Chairman, Modern Group, Mr.Shantanu Kharia, Vice President Modern Group Indore and for support for this study.

\section{References}

1. Douglas Mann L. Heart Failure and CorPulmonale. Fauci AS, Braunwald E, Kasper DL, Hauser SL, Longo DL, Jameson JL, et al. Harrisons Principles of Internal Medicine. 18t $\mathrm{t}^{\mathrm{h}}$ ed. New York: McGraw-Hill; 2008.

2. Robert Reilly F, Edwin Jackson K. Regulation of Renal Function and Vascular Volume. Laurence Brunton, Bruce Chabner, Bjorn Knollman. Goodman and Gilman's The Pharmacological Basis of Therapeutics. $12^{\text {th }}$ ed. New York:McGraw-Hill 2011.

3. Vats M, Sharma N, Sardana S. Antimicrobial activity of stem bark extracts of Nyctanthes arbortristis Linn. (Oleaceae) Inter Nyctanthes arbortristisional. Journal of Pharmacognosy and Phytochemical Research. 2009; 1:12-14

4. ]Meshram MM, Rangari SB, Kshirsagar SB, Gajbiye S, Trivedi MR, Sahane RS. Nyctanthes arbortristis-A herbal panacea. Inter Nyctanthes arbortristisional. Journal of Pharmaceutical Sciences and Research. 2012; 3(8):2432-40.

5. Kiew R, Baas P. Nyctanthes is a member of Oleaceae. Proc Indian Acad Sci. 1984; 3:349-58.

6. Kirtikar KR, Basu BD. Nyctanthes arbor-tristis in medicinal plants, edited by Blatter E, Cains JF, Mhaskar KS, (LM Basu Publishers, Allahabad, India), 1935, 536.

7. Amarite O, Bhuskat P, Patel N, Gadgoli C. Evaluation of antioxidant activity of carotenoid from Nyctanthes arbortristis. Int J Pharmacol Biol Sci. 2007; 2:57-59.

8. Omkar A, Jeeja T, Chhaya G. Evaluation of antiinflammatory activity of Nyctanthes arbortristi and Onosma echiodes. Phrmacog. mag., 2006; 8:258-60.

9. Pushpendra Kumar Jain, Debajyoti Das, Puneet Jain. Evaluating Hair Growth Activity of Herbal Hair Oil. Int J Pharm Tech Res. 2016; 9(3):321-27.

10. Menzes C, Gupta K, Satyanarayana D, Jagadish Kamath V. Evaluation of Diuretic activity of Ficusglomerat ROXB in experimental animal model. World Journal of Pharmacy and Pharmaceutical Sciences. 2013;2(1):253-58.

11. Tammu J, Venkata Ramana K, Thalla S, Narasimha Raju BH. Diuretic activity of methanolic extract of Physalis minima leaves. Der Pharmacia Lettre. 2012;4(6):1832-34.

12. Fang J, Mensah GA, Croft JB, Keenan NL. Heart failure-related hospitalization in the U.S., 1979 to 2004. Journal of the American College of Cardiology. 2008;52(6):428-34.

13. Mark Huffman D, Prabhakaran D. Heart failure: Epidemiology and prevention in India. The National Medical Journal of India. 2010;23(5):283-88.

14. Ningjun Li, Fan Yi, Christina Sundy M, Li Chen, Molly Hilliker L, Dustin Donley K, Daniel Muldoon B, et al. Expression and actions of HIF prolyl-4hydroxylase in the rat kidneys. American Journal of Physiology-Renal Physiology. 2007;292:F207- 16. 